\title{
The action of post-dispersal beetles (Coleoptera: Scarabaeidae) and ants (Hymenoptera: Formicidae) on scats of Didelphis spp. (Mammalia: Didelphidae)
}

\author{
Nilton Carlos Cáceres ${ }^{1} \&$ Emygdio L.A. Monteiro-Filho ${ }^{2}$ \\ 1 Universidade Federal de Santa Maria, Cx.P. 5044, Santa Maria, RS, 97.110-970, Brazil; nc_caceres@hotmail.com. \\ Fax: (55) 32208465. \\ 2 Departamento de Zoologia, Cx.P. 19020, Universidade Federal do Paraná, Curitiba, PR, 81.531-990, Brazil, e Instituto \\ de Pesquisas Cananéia, Rua João Salim, lote 26, quadra Y, Parque Xangrilá, Campinas, SP, 13.098-106, Brazil; \\ kamonteiro@uol.com.br
}

Received 28-IV-2003. Corrected 21-X-2005. Accepted 09-VIII-2006.

\begin{abstract}
A two year study of dung beetles and ants acting on scats of two species of opossum (Didelphis spp.) was carried out. Scats were left in the field in order to detect post-dispersal agents. A portion of each scat (30 $\%$ ) was examined for seeds in the laboratory. Beetles were recovered from burrows (51\% of 84 faecal samples left in the field) where they either buried scats of opossums or were attracted, together with ants, to pitfalls $(\mathrm{N}=10)$ baited with opossum scats. Dung beetles were the main post-dispersal agents of seeds found in scats of opossums, rolling the scats away or burying then on the site of deposition. They buried faeces at 4 to $15 \mathrm{~cm}$ in depth $(\mathrm{N}=22$ tunnels). The main dung beetles identified (medium to large size) were Eurysternus $(28.7 \%$ in pitfalls) and Dichotomius (13.7\%), Coprophanaeus (seen only directly on faeces), besides small-bodied beetles ( $<10 \mathrm{~mm} ; 57.6 \%)$. The ant Acromirmex sp. transported some seeds from scats. This species was present in 25.5 $\%$ of all Formicidae samples (pitfall). These post-dispersal agents contribute to avert scat seed predators such as rodents, and to accelerate seed bank formation. Rev. Biol. Trop. 54 (4): 1197-1203. Epub 2006 Dec. 15.
\end{abstract}

Key words: Seed dispersal, post dispersal insects, dung beetles, ants, marsupials, small mammals.

Soil arthropods, such as dung beetles and ants, have interactions with scats of mammals that can be very common. In general, these insects use scats for feeding and reproducing, transporting them to underground chambers dug in the soil (Marshall 1981, Hanski 1992, Levey and Burne 1993, Halffter et al. 1996, Martín-Piera and Lobo 1996).

Several studies have reported the action of dung beetles on scats of mammals such as howler monkeys (Alouatta palliata), spider monkeys (Ateles geoffroy) and coatis (Nasua narica) (eg. Chapman 1989, Estrada and Coates-Estrada 1991, Estrada et al. 1993). Nevertheless, most of them are about scats of cattle (Bos) and of humans, due to the great facility of collection and the expansion of livestock, compared to the already reduced areas of preserved forests (Kirk 1992, Flechtmann et al. 1995, Martín-Piera and Lobo 1996, Escobar 1997).

A conspicous group of mammals, the marsupials, are considered seed dispersers (Atramentowicz 1988, Cáceres and MonteiroFilho 2001, Cáceres 2002, Pinheiro et al. 2002), but nothing is known about the action of postdispersal insects on seeds from scats. Based on this, a study of the interaction between dung beetles and ants on scats of Didelphis was carried out in a forest fragment in southern Brazil, where two species of opossums, Didelphis albiventris (Lund, 1840) and D. aurita (WiedNewied, 1826), live in simpatry. 


\section{MATERIALS AND METHODS}

The study area was an urban forest fragment of 5 ha located in the municipality of Curitiba, PR $\left(25^{\circ} 25^{\prime} \mathrm{S} ; 49^{\circ} 18^{\prime} \mathrm{W}\right)$, at $940 \mathrm{~m}$ asl, in the south of Brazil. The area is covered by disturbed mixed ombrophyllous forest (Araucarian Forest). The average annual temperature is $17^{\circ} \mathrm{C}$, with frosts during the coldest months (June-July). The warmest and rainiest months are from October to March, though there is not a well defined rainy season. April is the driest month (Maack 1981).

Nine field phases were conducted between November 1998 and July 2000 to research the occurrence of post-dispersal agents on scats of Didelphis. To collect scats, four consecutive nights of trapping were carried out in each field phase, utilizing 20 to 30 live traps baited with banana and codfish liver oil. Part of each scat $(30 \%)$ was evaluated for the presence of seeds. After the release of the trapped animals, their faecal samples were monitored at distances from 2 to $3 \mathrm{~m}$ during $30 \mathrm{~min}$ to $1 \mathrm{~h}$, in order to find possible post-dispersal agents on scats (method of direct observation). During part of the field phases, scats buried by dung beetles were recovered by digging in the site, in order to determine the beetle species (method of rediscovering faecal samples). Dung beetles build a specific entrance when they bury a scat, easily discernible in the field.

Additionally, faecal samples of Didelphis were also placed as baits to attract dung beetles and ants in order to investigate their diversity and local abundance (method of pitfall). These scats ( 5 to $25 \mathrm{~g}$ ) were coiled with a commercial cloth wick and hung by means of a wooden stick on a container $(500 \mathrm{ml})$ with water $(2 \mathrm{~cm}$ of column of water) buried at soil level (pitfall). Five containers were placed in the edges of the forest fragment (considering $2 \mathrm{~m}$ as the effective edge), spaced $20 \mathrm{~m}$ from each other, and other five containers were placed in the interior of the fragment (at least $50 \mathrm{~m}$ from the effective edge), spaced $50 \mathrm{~m}$ from each other randomly. Containers were set and checked for four consecutive days during April, July (the driest season) and October (the wettest season) 2000, and the insects found were collected and preserved in $70 \%$ alcohol. Voucher beetle and ant specimens were deposited at the Instituto Biológico de São Paulo (the Biological Institute of São Paulo) and the Museu de Zoologia - USP, São Paulo (the Zoology Museum - USP, São Paulo), Brazil, respectively.

Some seed species identified as part of the diet of Didelphis were tested for their capacity to germinate when buried by dung beetles at different depths. For each species, a group of seeds was buried at depths from 1 to $5 \mathrm{~cm}$ in glass pots and control seed groups were placed on the soil surface, also in glass pots, both in laboratory conditions. Seeds of the respective species found in scats were collected from ripe fruits in the study area, for these experiments

\section{RESULTS}

Observations of the destination of the scats left in the field $(\mathrm{N}=84)$ showed that about $51 \%$ of them were visited by dung beetles and were transported by them to chambers dug (a) in the same site of the original position of the scats (the tunnellers) and (b) far from the scats (the rollers). In most times, from $90 \%$ to $100 \%$ of total faecal samples were buried. However, there was a tendency for sampling large-sized beetles $(1.5$ to $3.0 \mathrm{~cm})$ because it was easier to find tunnels near the original position of the scats (method of recovering faecal samples). Small beetles (mostly tunnellers) were therefore not detected in many cases by using this method. However, direct observations of scats $(\mathrm{N}=25 \mathrm{~h})$ and pitfalls revealed the action of these small-bodied coprophagous coleopterans. Small-bodied beetles and ants that interact on faeces of Didelphis (data from pitfalls) were numerically dominant (Table 1), as follows.

Coprophanaeus saphirinus Sturm, 1826 $(2.16 \pm 0.48 \mathrm{~cm} ; \mathrm{N}=2)$ was the largest species registered by the study. From 22 scats recovered in tunnels, this species was found only in two occasions ( $9 \%$ ), one of them on scats of D. aurita. C. saphirinus showed diurnal habits, 
TABLE 1

Number of dung beetles and ants attracted to scats of Didelphis using pitfalls in an urban forest fragment of 5 ha in southern Brazil during colder and warmer months of 2000

Species or group

$\mathrm{N}^{\mathrm{o}}$ of individuals

Total

Behaviour

Habit
April
July
October
on scats

Scarabeidae and relaters

\begin{tabular}{|c|c|c|c|c|c|c|}
\hline Dichotomius assifer & $29 / 1$ & $16 / 0$ & $21 / 0$ & $66 / 1$ & Tunneler & Nocturnal \\
\hline Eurysternus cyanescens & $80 / 12$ & $0 / 0$ & $41 / 7$ & $121 / 19$ & Endocoprid $^{1}$ & Diurnal \\
\hline Coleopterans of 5 to $10 \mathrm{~mm}$ & $6 / 0$ & $41 / 0$ & $7 / 1$ & $54 / 1$ & $\begin{array}{c}\text { Roller } \\
\text { Tunneler }\end{array}$ & Varied \\
\hline Coleopterans $<5 \mathrm{~mm}$ & $81 / 6$ & $21 / 1$ & $104 / 13$ & $206 / 20$ & $\begin{array}{c}\text { Roller } \\
\text { Tunneler }\end{array}$ & Varied \\
\hline rmicidae & & & & & & \\
\hline Acromirmex spp. & $0 / 0$ & $9 / 0$ & $301 / 3$ & $310 / 3$ & Loader & Diurnal \\
\hline Other ants & $26 / 90$ & $12 / 25$ & $503 / 258$ & $541 / 373$ & Not determined & Varied \\
\hline
\end{tabular}

Numbers of individuals sampled in the interior of forest fragment and edges are supplied, respectively.

1 Behaviour: staying within scats, does not transport them.

being observed burying scats of Didelphis in one occasion, foraging under litter and flying above two scats, all of which during the day. This is a species that depicts a shiny blue colour, easily discernible in the field. A $C$. saphirinus individual buried an opossum scat at a depth of $7 \mathrm{~cm}$ on one occasion. It is a species of generalist feeding habits since it was seen in the study area burying an Oligoryzomys nigripes (Olfers, 1818) carcass, showing thus a coprophagous-necrophagous feeding habit.

Dichotomius assifer (Eschscholtz, 1822) (Mean \pm SD: $1.92 \pm 0.11 \mathrm{~cm} ; \mathrm{N}=10$ ) was the second most abundant species of dung beetle in the study area, medium to large in size (Fig. 1). This species has never been seen during diurnal observations of scats and was only found by means of excavations in tunnels (which were made during the night). Using this method, D. assifer was found in $55 \%$ of the tunnels $(\mathrm{N}$ total $=22$ ), close to buried scats, just below the point where the scats had been left the day before. However, D. assifer was the main loader of scats (Table 1), burying almost $100 \%$ of every faecal sample. The pitfall method pointed out the even bigger abundance of $D$. assifer in the fragment all year round, though population levels have decreased a little (July). D. assifer buried scats at an average depth of $8.3 \pm 4.3 \mathrm{~cm}$ $(\mathrm{N}=8)$, with a minimum range of $4 \mathrm{~cm}$ and a maximum of $15 \mathrm{~cm}$. D. assifer, similarly to other dung beetle species, occurred mostly in the interior of the forest fragment rather than in the edges (Table 1).

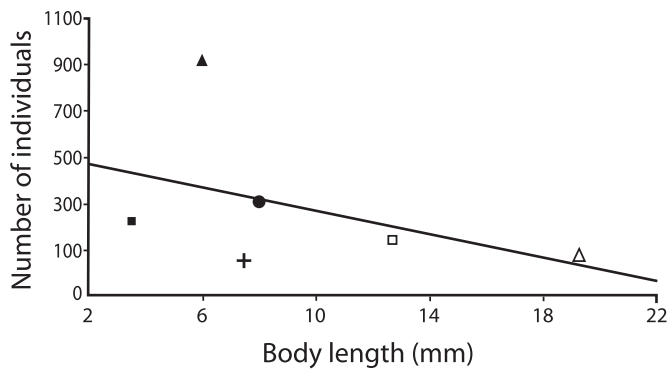

Fig. 1. Abundance and body size of dung beetles (DB) and ants (observed by pitfalls) on scats of Didelphis at a small forest fragment in southern Brazil. From left to right: $\mathrm{DB}$ with modal size class size $=3.5 \mathrm{~mm}$; ants with modal class $=6.0 \mathrm{~mm}$; DB with modal class $=7.5 \mathrm{~mm}$; Acromirmex spp. (circle); Eurysternus cyanescens (white square), Dichotomius assifer (white triangle). 
Eurysternus cyanescens (Balthazar, 1939), $(1.27 \pm 0.08 \mathrm{~cm} ; \mathrm{N}=14)$ was the most abundant dung beetle species in the fragment. It is an endocoprid species, staying under or inside scats. Its population levels increased during the wet season but strongly decreased in the cold season (July). In general, one to eight individuals per sample were seen on scats of Didelphis. It seems to tolerate the environment in the edges better than $D$. assifer (Table 1).

Small-bodied coleopterans (2 to $10 \mathrm{~mm}$ ). These dung beetles also occurred in considerable numbers within the fragment, mainly in its interior (Table 1). Among them, Agamopus sp. ( 5 to $7 \mathrm{~mm}$ ), a diurnal roller beetle, was seen in two occasions pushing small pieces of scats, with the aid of its hind legs. On the other hand, individuals of Canthidium sp. were collected close to scats, however in the interior of underground chambers at low depths in the soil (1 to $3 \mathrm{~cm}$ ). Other small-bodied dung beetles, such as hibosorines, were occasionally collected close to scats, in the interior of underground chambers built by large dung beetles.

Leaf-cutting ants (Acromirmex spp.) were registered transporting small pieces of Didelphis's scats. An individual of this genus was seen transporting a seed of Passiflora removed from scats of Didelphis. Acromirmex spp. were abundant in the interior of the fragment in October, whereas the abundance of other ants was seasonal and site-dependent (edge or interior; Table 1).

From scats collected $(\mathrm{N}=64), 51 \%$ had one or more seed species. These seeds belonged to four identified families and nine genera distributed among 12 species of plants. The most frequent species in scats were Piper gaudichaudianum Kunth (Piperaceae; $\mathrm{N}=826$ seeds; $30 \%$ of occurrence in scats), Solanum maioranthum L.B.Sm. $(\mathrm{N}=170,11 \%)$ and Vassobia breviflora (Sendtn.) Munz (Solanaceae; N=30; 8 \%). Passiflora actinia Hooker (Passifloraceae; only seed fragments in scats) seeds also appeared in scats but usually in low numbers.

Experiments with the germination of seeds buried in soil under laboratory conditions showed that seed species dropped by opossums can germinate when buried up to $5 \mathrm{~cm}$ in depth. Seeds of Physalis pubescens L. (absent in the scats, but see Cáceres 2002) germinated only on the soil surface when submitted to weak light intensity (or in shade condition), whereas when submitted to strong light intensity (near full light), seeds buried at $1 \mathrm{~cm}(\mathrm{~N}=25)$ as well as at $5 \mathrm{~cm}(\mathrm{~N}=40$, but from scats) germinated at similar rates (84\% and $50 \%$, respectively) to those of the control experiments on the soil surface. Seeds of $P$. actinia germinated only at $1 \mathrm{~cm}$ and $5 \mathrm{~cm}$ in depth in the soil $(\mathrm{N}=20$, $60 \%$; $=20,45 \%$, respectively) and not on the soil surface. P. gaudichaudianum germinated only on the soil surface $(\mathrm{N}=25,84 \%)$.

\section{DISCUSSION}

The assemblage of dung beetles registered in the forest fragment studied for scats of opossums was similar to others found elsewhere in the neotropics, with the presence of genera such as Dichotomius, Eurysternus, Agamopus and Canthidium, which have the same role in the destination of scats, that is, tunnellers, rollers and endocoprids (Estrada and Coates-Estrada 1991, Kirk 1992, Estrada et al. 1993, Flechtmann et al. 1995, Escobar 1997). However, these assemblages were registered by using different types of scats, such as of primates, carnivores, cattle and humans, showing a certain degree of flexibility in the feeding habits for these dung beetle genera.

At least in what concerns the volume of scats buried, there was, apparently, the dominance of a nocturnal species, D. assifer, within the forest fragment. The forested habitat appears to favour the dominance of nocturnal dung beetles (Halffter et al. 1992). The dominance of some species of dung beetles in fragmented landscapes seems to be common (Kirk 1992, Escobar 1997). Considering the hypothesis of competition between tunnellers for scats of opossums in the forest fragment, this phenomenon would be diminished by the niche separation of $D$. assifer and $C$. saphirinus, since one is nocturnal and coprophagous 
and the other, diurnal and generalist (coprophagous-necrophagous). This explained the lower occurrence of $C$. saphirinus on opossum scats found by the method of rediscovering scats. Generalist dung beetles are common in other regions of the Americas and elsewhere (Hanski 1992). The activity time, body size and manner of transporting scats are the main strategies for resource partitioning among Neotropical scarabaeid beetles (Halffter et al. 1992, Hanski 1992, Kirk 1992).

Due to the fact that near $100 \%$ of most faecal samples were buried by $D$. assifer, this species, like the remaining small-bodied species, is contributing to the aeration of the soil and the formation of seed banks, since scats of Didelphis usually contain a lot of seeds (Cáceres and Monteiro-Filho 2001, Cáceres 2002). Thus, small-bodied beetles should each time move small pieces of scats, having a different role in seed dispersion. According to Estrada and Coates-Estrada (1991), these small balls may contain small seeds (rather than large ones) that are often buried by these beetles at low depths (Cambefort and Hanski 1991). Small seeds $(<7 \mathrm{~mm})$ are very common in the scats of Didelphis (Cáceres 2002) and can germinate at low depths as seen here.

Depths at which seeds were buried here were similar to those found for dung beetles on howler monkeys' scats in Mexico (Estrada and Coates-Estrada 1991). In that study, depths were suitable for seed germination, just as it occurred experimentally here for some seed species in opossum scats. For example, $P$. actinia seeds need complete shadow for germination (Cáceres and Monteiro-Filho, unpubl.), a condition easily obtained with the aid of dung beetles. In fact, seeds present in opossum scats are mainly pioneer in forest succession (Cáceres 2002). Strong rains usually open gaps in the forest, occasioned by tree falls, turning over litter and uncovering buried pioneer seeds (Charles-Dominique and Puig 1999).

Tunneller and roller dung beetles prevent seeds in scats from being preyed on by predators such as some rodents (Perry and Fleming 1980, Chapman 1989). This was satisfactorily tested for seeds in scats of howler monkeys A. palliata (Estrada and Coates-Estrada 1991). Such dung beetles, like $D$. assifer and C. saphirinus, as well as their larvae in the underground chambers, do not damage the seeds because of their soft membranaceous buccal apparatuses for feeding on remains of excrements (Halffter and Matthews 1966, Cambefort 1991, Halffter 1991, S. Ide, pers. com). Since several species dispersed by Didelphis show dormancy (Cáceres 2002, unpubl.), they may wait for good conditions of germination in these chambers. The scattering of faecal balls by rollers from the original position of the scat is also an important factor to avoid seed predation. The presence of lot of seeds inside the same scat, as usually occurs with Didelphis and other marsupials (Cáceres and Monteiro-Filho 2001, Cáceres 2002), is extremely attractive for seed predators such as rodents (Perry and Fleming 1980).

Ants, such as Acromirmex, did help the mammalian seed dispersal by transporting them to suitable sites of germination (Perry and Fleming 1980, Levey and Byrne 1993). Ants were also seen transporting Philodendron cf. imbe Schott (Araceae) seeds from D. aurita scats in the Atlantic Forest (N.C. Cáceres, pers. obs.). They may play an important role in secondary seed dispersal, as estimated here for the interior of the forest fragment as well as for the forest edges. Some opossum species usually forage in the edges of forest fragments (N.C. Cáceres, unpubl.), particularly the small ones, propitiating seed deposition on these places (Pinheiro et al. 2002).

Opossums are the most abundant and one of the largest wild mammalian species in small, urban forest fragments (Fonseca and Robinson 1990, Cáceres 2002). And, due to the big amount of biomass produced by them, must be one of the most important sources of scats for dung beetles in disturbed, forested environments.

\section{ACKNOWLEDGMENTS}

We are in debt to S. Ide and C. Brandão for identification of beetles and ants, respectively, 
to J.G. Loreley Oviedo for assistance with the abstract in Spanish, and S. Bichara-Desecki for assistance in the English translation. The "Curso de Pós-Graduação em Zoologia" at UFPR gave support to this study. CAPES granted a fellowship to NCC.

\section{RESUMEN}

Por dos años estudiamos los escarabajos coprófagos y las hormigas que actúan en las heces de zarigüellas (Didelphis). Se dejaron excrementos en el campo para descubrir los agentes secundarios de dispersión. Una parte de cada excremento (30\%) fue analizada en laboratorio para estimar el número de semillas. Se recolectaron escarabajos del suelo (51\% de 84 excrementos dejados en el campo). También capturamos escarabajos y hormigas con trampas $(\mathrm{N}=10)$. Los escarabajos coprófagos son los principales agentes secundarios de dispersión. Ruedan los excrementos o los entierran a $4-15 \mathrm{~cm}$ de profundidad $(\mathrm{N}=22$ túneles). Los escarabajos coprófagos de mayor tamaño fueron Eurysternus cyanescens (28.7\% en trampas), Dichotomius assifer $(13.7 \%)$ y Coprophanaeus saphirinus (sólo visto en madrigueras y directamente sobre los excrementos). Los escarabajos de menos de $10 \mathrm{~mm}$ fueron el $57.6 \%$. La hormiga Acromirmex sp. fue $25.5 \%$ del total de hormigas capturadas en trampas. Hallamos varias especies de semillas en los excrementos, muchos de ellos enterrados por los escarabajos, y algunas fueron extraídas por las hormigas. Estos agentes secundarios ayudan a evitar los depredadores de semillas (eg. roedores) y aceleran la formación del banco de semillas, pues no las comen.

Palabras clave: dispersión de semillas, dispersión secundaria, escarabajos coprófagos, hormigas, marsupiales, mamíferos pequeños.

\section{REFERENCES}

Atramentowicz, M. 1988. La frugivorie opportuniste de trois marsupiaux didelphidés de Guyane. Rev. Ecol. Terre Vie 43: 47-57.

Cáceres, N.C. 2002. Food habits and seed dispersal by the white-eared opossum, Didelphis albiventris (Mammalia, Marsupialia), in southern Brazil. Stud. Neotrop. Fauna Environ. 37: 97-104.

Cáceres, N.C. \& E.L.A. Monteiro-Filho. 2001. Food habits, home range and activity of Didelphis aurita (Mammalia, Marsupialia) in southern Brazil. Stud. Neotrop. Fauna Environ. 36: 85-92.
Cambefort, Y. 1991. From saprophagy to coprophagy, p. 37-50. In I. Hanski \& Y. Cambefort (eds.). Dung beetle ecology. Princeton, Massachusetts, USA.

Cambefort, Y. \& I. Hanski. 1991. Dung beetle population biology, p. 37-50. In I. Hanski \& Y. Cambefort (eds.). Dung beetle ecology. Princeton, Massachusetts, USA.

Chapman, C.A. 1989. Primate seed dispersal: the fate of dispersed seeds. Biotropica 21: 148-154.

Charles-Dominique, P. \& H. Puig. 1999. Régénération des forêts tropicales humides, l'exemple de la Guyane, $\mathrm{p}$. 28-36. In Forêts tropicales: des connuissonces par le gestion. Ministère de l'Aménagement du Territoire et de l'Environnement, Paris, France.

Escobar-S., F. 1997. Estudio de la comunidad de coleopteros coprófagos (Scarabaeidae) en un remanente de bosque seco al norte del Tolima, Colombia. Caldasia 19: 419-430.

Estrada, A. \& R. Coates-Estrada. 1991. Howler monkeys (Alouatta palliata), dung beetles (Scarabaeidae) and seed dispersal: ecological interactions in the tropical rain forest of Los Tuxtlas, México. J. Trop. Ecol. 7: 459-474.

Estrada, A., G. Halffter, R. Coates-Estrada \& D.A. MerittJr. 1993. Dung beetles attracted to mammalian herbivore (Alouatta palliata) and omnivore (Nasua narica) dung in the tropical rain forest of Los Tuxtlas, México. J. Trop. Ecol. 9: 45-54.

Flechtmann, C.A.H., S.R. Rodrigues \& C.L. Gaspareto. 1995. Controle biológico da mosca-dos-chifres (Haematobia irritans) em Selvíria, Mato Grosso do Sul. 5. Seleção de besouros coprófagos. Rev. Bras. Ent. 39: 277-286.

Fonseca, G.A.B. \& J.G. Robinson. 1990. Forest size and structure: competitive and predatory effects on small mammal communities. Biol. Cons. 53: 265-294.

Halffter, G. 1991. Feeding, bisexual cooperation and subsocial behavior in three groups of Coleoptera, $\mathrm{p}$. 281-296. In M. Zunino, X. Bellés \& M. Blas (eds.). Advances in coleopterology. AEC, Barcelona, Spain.

Halffter, G. \& E.G. Matthews. 1966. The natural history of dung beetles of the Subfamily Scarabaeinae (Coleoptera, Scarabaeidae). Folia Ent. Mex. 12-14: 1-312.

Halffter, G., M.E. Favila \& V. Halffter. 1992. A comparative study of the structure of the scarab guild in Mexican tropical rain forests and derived ecosystems. Folia Ent. Mex. 84: 131-156. 
Hanski, I. 1992. Dung beetles, p. 489-511. In H. Lieth \& M.J.A. Werger (eds.). Ecosystems of the world tropical rain forest ecosystems: biogeographical and ecological studies. Elsevier, Amsterdam, Netherlands.

Kirk, A.A. 1992. Dung beetles (Coleoptera: Scarabaeidae) active in patchy forest and pasture habitats in Santa Cruz Province, Bolivia, during spring. Folia Ent. Mex. 84: 45-54.

Levey, D.J. \& M.M. Byrne. 1993. Complex ant-plant interactions: rain forest ants as secondary dispersers and postdispersal seed predators. Ecology 74: 1 802-1 812.

Maack, R. 1981. Geografia física do Estado do Paraná. J. Olympio, Rio de Janeiro, Brazil. 450 p.
Marshall, A.G. 1981. The ecology of ectoparasitic insects. Academic, London, England.

Martín-Piera, F. \& J.M. Lobo. 1996. A comparative discussion of trophic preferences in dung beetle communities. Miscel. Zool. 19: 13-31.

Perry, A.E. \& T.H. Fleming. 1980. Ant and rodent predation on small, animal-dispersed seeds in a dry tropical forest. Brenesia 17: 11-22.

Pinheiro, P.S., F.M.V. Carvalho, F.A.S. Fernandez \& J.L. Nessimian. 2002. Diet of the marsupial Micoureus demerarae in small fragments of Atlantic forest in southeastern Brazil. Stud. Neotrop. Fauna Environ. 37: 213-218 
